Research Article

\title{
Antimicrobial Production by an Actinomycetes Isolated from the Termite Nest
}

\author{
Ni Putu Ratna Ayu Krishanti *, Deni Zulfiana, Bramantyo Wikantyoso, Apriwi Zulfitri, Sulaeman \\ Yusuf
}

Research Center for Biomaterials, Indonesian Institute of Sciences, Bogor 16911, Indonesia

\section{Article history:}

Submission August 2018

Revised August 2018

Accepted September 2018

*Corresponding author:

E-mail: ratna.a.krishanti@gmail.com

\begin{abstract}
Actinomycetes are Gram positive bacteria that have been detected in diverse ecological niches. Their member species are known to be a main source of various bioactive compounds. The discovery of Actinomycetes from diverse and unexplored resources has also been linked to increased opportunities to obtain novel bioactive compounds. Insect nest material is being investigated as a new source of novel antimicrobial producing Actinomycetes, which could be harnessed for therapeutic potential. A total of 10 Actinomycetes isolates were collected from the nest of Nasutitermes sp. in Pananjung Pangandaran Nature Reserve. These isolates were evaluated for antimicrobial activity against the challenge bacteria (Eschericia coli, Staphylococcus aureus, Bacillus subtilis, Serratia marcescens) and fungi (Fomitopsis palustris, Fusarium oxysporum, Trichoderma viridae) by dual culture method. The result revealed that several isolates were active against fungi and bacteria. Isolate Pn-TN2 showed the highest level of antibacterial inhibition and the highest antifungal inhibition with Inhibition Rate value more than $80 \%$. By morphological and 16S rRNA gene sequence analysis strongly suggested that the isolate Pn-TN2 belonged to Streptomyces prasinopilosus. We suggested that termite nest is a potential source of bioactive strains of cultivable Actinomycetes for future biotechnological needs.
\end{abstract}

Keywords: Actinomycetes, antimicrobial, Nasutitermes sp., Streptomyces prasinopilosus, termite nest

\section{Introduction}

Actinomycetes are Gram-positive bacteria that are known to produce variety of bioactive compounds covering approximately $70 \%$ of bioactive compounds produced by bacteria [1, 2]. Actinomycetes are widely distributed in nature, and typically useful in the pharmaceutical industry for their capacity to produce secondary metabolites with diverse chemical structures and biological activities such as antibiotics, enzyme inhibitors and enzymes that degrade organic matter [3]. Among the bioactive compound derived from Actinomycetes, $75 \%$ are produced by Streptomyces spp. and $25 \%$ are produced by the non-Streptomyces group. Although thousands of antibiotics have been isolated from Streptomyces, these represent only a small fraction of the repertoire of bioactive compounds produced [4]. Therefore, isolation of new
Streptomyces from natural resources and characterization for their secondary metabolites is important to increase opportunities to obtain novel bioactive compounds [5]. Insect associated microbes present promising sources of novel bioactive compounds that are only beginning to be discovered and exploited [6].

Termites are a group of social insects that are classified as the order of Isoptera, which is closely related to cockroaches [7]. They live in large colonies comprises a king, queen, soldiers and workers, each of which has different behaviors and functions $[8,9,10]$. Soil termites play an important role in circulating nutrients from decaying dead plant materials in the soil ecosystem [11]. Termite colonies are often found in a protective structure called a "termite nest". The termite nest is made from a mineral matrix mixed by the depo-

How to cite:

Krishanti NPRA, Zulfiana D, Wikantyoso B et al. (2018) Antimicrobial Production by an Actinomycetes Isolated from The Termite Nest. Journal of Tropical Life Science 8 (3): 279 - 288. doi: 10.11594/jtls.08.03.10 
sition of clay particles or plant materials, organic carbon, with feces or saliva, depending on the termite species and forms a specific habitat for soil microbes since the physical and chemical properties are different from the surrounding soil [12, 13]. There are three types of termite nest, which are mounds nest (upper ground), carton nest (on trees), and subterranean nest (underground). The type of a nest constructed depends on the feeding habit of the termite's species [14]. The nest-walls consist of organo-mineral aggregates, characterized by a low stability and mineralize easily [15]. It has a wider range of activity on the surrounding soil of $1-3 \mathrm{~m}$ in depth and within a range of $2-$ $8 \mathrm{~m}$ [16], which may influence the soil properties, fertility, and microbial composition including bacteria and fungus.

Recent studies reported that Actinomycetes were identified as one of the dominant bacteria in this symbiotic of termite's lifestyle. These symbiotic between Actinomycetes and termites provides assisting functions for termites, such as nutrient cycling and exchange, and also protect termites from invading pathogens [13]. Some of these termite-associated Actinomycetes may also exhibit lignin-cellulolytic activity [17] and antagonistic activity against diverse pathogens [10, 18]. Furthermore, some novel and prospective novel species of Actinomycetes associated with termites have been reported degraded hemicellulose compound, showed antiviral activity, and produced antibiotic compound such as microtermolides and natalamycin [19, 20, 21, 22].

The aim in this present study was to investigate the generic and functional diversities of cultivable Actinomycetes obtained from termite nest. A preliminary investigation of antimicrobial activity of Actinomycetes associated with the termite's nest using dual culture methods and assessment in vitro microbial growth inhibition capability were also conducted. We used a total of 7 bacterial and fungal isolates for antagonistic assay. Bacillus subtilis, Eschericia coli, and Pseudomonas aeroginosa are known as pathogenic bacteria human pathogenic bacteria. The isolated Actinomycetes were also challenged against one of main causal for many plant diseases, Fusarium oxysporum, and a wood fungus or known as brown rot fungi, Fomitopsis palustris. We also applied Serratia marcescens and Trichoderma viride which are being developed as plants biocontrol agents to the as- say. Various types of bacterial and fungal test isolates are used to explore the potential of antimicrobial compounds that produced by the isolated Actinomycetes. The implication of termite nests as a potential source for novel antimicrobial producing-Actinomycetes in the future was also discussed.

\section{Material and Methods \\ Preparation of termite nest sample}

Sample of termite nest was collected in September 2016 from Pananjung Pangandaran Nature Reserve, West Java, Indonesia. Termite nest was obtained by cruise method. The type of collected nest termite was carton nest. Termite nest samples (200 g per sample) were placed in polyethylene bags and immediately transported to Microbiology Laboratorium of Research Center for Biomaterials- LIPI. Termites sample (worker and soldier) inhabiting the nest were collected and preserved in $70 \%$ alcohol tube. The termites were identified based on key identification according to Ahmad [23] and Syaukani [24]. Photographs were taken with digital microscope with $40-80 \times$ magnification. Nest samples were ground into fine particles and air-dried at an ambient temperature for 7 days before the isolation of Actinomycetes.

\section{Isolation of Actinomycetes}

Isolation of Actinomycetes from termite nest was done based on Kang [25] methods. Ten grams of grounded termite nest were heated at $70^{\circ} \mathrm{C}$ for 15 minutes. Serial dilutions of treated sample were prepared in sterile physiological saline and inoculated onto duplicate plates of humic acid-vitamin (HV) agar medium [26]. Humic acid-vitamin agar was prepared as described previously [27]. It is a minimal medium containing $\mathrm{Na}_{2} \mathrm{HPO}_{4}$ 0.05\%; $\mathrm{KCl} 0.17 \%, \mathrm{MgSO}_{4} .7 \mathrm{H}_{2} \mathrm{O} 0.005 \%, \mathrm{FeSO}_{4} .7 \mathrm{H}_{2} \mathrm{O}$ $0.001 \%, \mathrm{CaCO}_{3} 0.002 \%$ at $\mathrm{pH} 7.2$, supplemented with $0.1 \%(\mathrm{w} / \mathrm{v}$ ) of humic acid (Sigma Chemicals) as carbon source. Inhibitor agen such as nalidixid acid and cycloheximide were added $50 \mathrm{ppm}$ respectively to reduce contamination. The vitamin solution $(0.00005 \%$ each of thiamine $\mathrm{HCl}$, riboflavin, niacin, pyridoxine- $\mathrm{HCl}$, inositol, Ca-pantothenate, p-aminobenzoic acid, and $0.000025 \%$ of biotin) was made separately, filter sterilized, and added after the medium was autoclaved. Single colonies of isolates were pick up and purified in Yeast Extract Malt Extract Agar (ISP2) for further 
use.

\section{Isolates of antagonist microorganisms}

The bacterial and fungal isolates, which were: F. palustris, T. viridae, B. subtilis, and S. marcescens used for this study were collection of Microbiology Laboratorium, Research Center for Biomaterials-LIPI, while F. palustris, Eschericia coli ATCC 8739, and S. aureus ATCC 25923 were obtained from Bogor Agricultural University Culture Collection (IPBCC). All the fungal isolates were maintenance in potato dextrose agar (PDA) media and bacterial isolates were cultured in $\mathrm{Nu}-$ trien Broth agar (NA) media. The isolates were stored at $4^{\circ} \mathrm{C}$ in tubes containing agar (PDA) for working stock. For long term preservation, it was stocked in glycerol solution at $-20^{\circ} \mathrm{C}$.

\section{Antibacterial test}

The antibacterial test was conducted based on Quintana [28] methods. Isolated Actinomycetes were streaked $2 \mathrm{~cm}$ wide on a $9 \mathrm{~cm}$ wide ISP2 agar plate and incubated for 7 days at $30^{\circ} \mathrm{C}$ to allow growth, sporulation, production and diffusion of metabolites. After 7 days, 4 antagonist bacteria (E. coli, S. aureus, B. subtilis, S. marcescens) were streak out in perpendicular position $5 \mathrm{~cm}$ (right to left) of the plate (Figure 1A). The plates were incu-
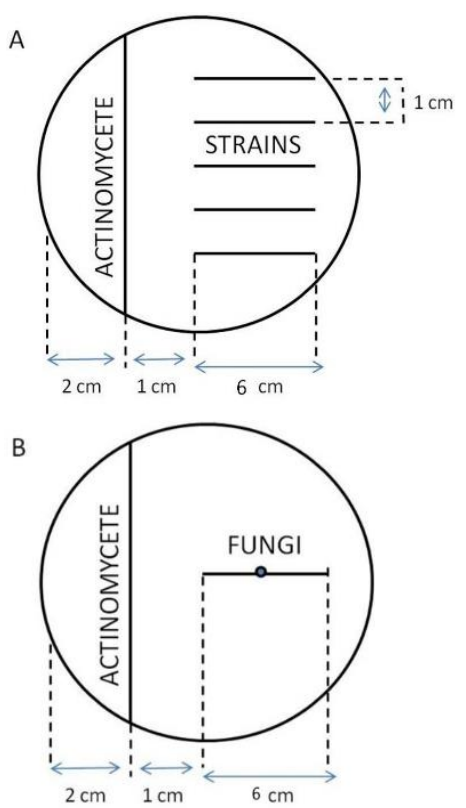

Figure 1. The streak technique for evaluation of antibacterial activity (A) and the streak technique for evaluation of the activity against pathogenic fungi (B) bated for 48 hours at $30^{\circ} \mathrm{C}$ and observed visually. Antibacterial activity was scored as positive when the opponent bacteria was failed to grow when no bacterial test growth was observed in the middle of agar plate after comparing to a control agar plate which contained no Actinomycetes.

\section{Antifungal test}

The Actinomycetes isolates were evaluated for their antifungal activity against 3 pathogenic fungal: Fomitopsis palustris, Fusarium oxysporum, and Trichoderma viridae by dual-culture in vitro assay [29]. Isolated Actinomycetes were streaked on a $2 \mathrm{~cm}$ wide ISP2 agar plate and incubated for 7 days at $30^{\circ} \mathrm{C}$ to allow growth, sporulation, production and diffusion of metabolites. A mycelial disk (6 $\mathrm{mm}$ in diameter) of 3 fungus were then inoculated on the plate and incubated for an extra 7 days at $30^{\circ} \mathrm{C}$ (Figure 1B). The percentage growth inhibition rate (IR \%) of Actinomycetes was was decided by:

$$
I R(\%)=100-(a / b \times 100)
$$

Note:

a: The mycelial growth of fungal test isolates towards

b: The mycelial growth of fungal test isolates away

\section{Molecular identification based on $16 S$ rRNA gene}

The identity of the selected strains was determined based on the amplification and sequencing of 16S rRNA gene. Bacterial genomic DNA was extracted using bacterial genome isolation kit (Genomic Mini Kit of Geneaid GP100). The integrity of the genomic DNA was visualized by gel electrophoresis in $1 \%(\mathrm{w} / \mathrm{v})$ by using the gel documentation system. 16S rRNA gene sequences were amplified using universal primer 16S rRNA gene for bacterial domain 27f (5'-AGA GTT TGA TCM TGG CTC AG-3') and 1492r (5'-TAC GGY TAC CTT GTT ACG ACT T-3') [30] with a length of $\sim 1300$ bp amplicon targets. The PCR reaction mixture was carried out in $50 \mu \mathrm{L}$ total volume, containing $8 \mu \mathrm{L}$ genomic DNA (50 ng/ $\mu \mathrm{L}$ ), $25 \mu \mathrm{L}(10 \mathrm{x}) \mathrm{mix}$ PCR (Go Taq Green Promega), $4 \mu \mathrm{L}(10 \mathrm{pmol})$ each primer and $9 \mu \mathrm{L}$ nuclease free water. The PCR conditions consisted of an initial denaturation at $94^{\circ} \mathrm{C}$ for 5 minutes, followed by 30 amplification cycles of denaturation at $94^{\circ} \mathrm{C}$ for 30 seconds, annealing at $55^{\circ} \mathrm{C}$ for 30 seconds, extension at $72^{\circ} \mathrm{C}$ for 1 minutes and a final extension of 


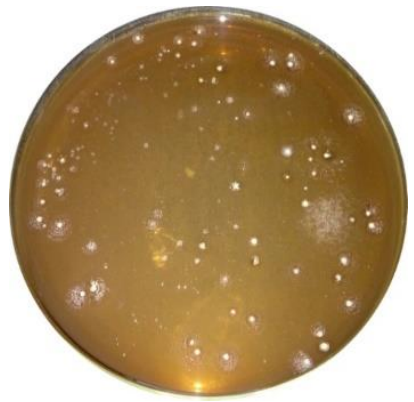

Figure 2. Actinomycetes isolates growth in HV agar media

7 minutes at $72^{\circ} \mathrm{C}$. The amplified PCR product was separated on $1 \%$ agarose gel using $1 \times \mathrm{TAE}$ buffer and examined under gel documentation system. The amplified amplicon was purified and sequenced commercially at First Base, Singapore.

Sequences of $16 \mathrm{~S}$ rRNA gene were analyzed for homology using BlastN search program and very closely related species showing high level of identity $(97-100 \%)$ was considered as closest match. These sequences, along with other Actinomycetes strains retrieved from NCBI GenBank (www.ncbi.nlm.nih.gov) were used for the construction of phylogenetic tree after pairwise aligned using MEGA 5.2 software.

\section{Results and Discussion \\ Isolation of Actinomycetes from termite's nest sample}

In this research, we using $\mathrm{HV}$ agar media to isolate Actinomycetes from the termite's nest sample. Its classify into nutrient-poor media therefore not many other microorganisms are able to live and utilize nutrients available in the media other than Actinomycetes bacterial group [3]. In the process of Actinomycetes isolation we added inhibitors compound and conducted heat pre-treatment method. The inhibitors were nalidixid acid and cycloheximide that is antibacterial and antifungal respectively. The addition was intended to increase number of selected Actinomycetes in media [31]. Otherwise, the sample was conducted airdried treatment for 7 days and preheated for 15 minutes at $70^{\circ} \mathrm{C}$ in order to reduce contamination from other fast-growing non-spore bacteria. Many spores of most Actinomycetes genera are more resistant to drought so that pre-treatment can be decreasing density of Gram negative bacteria [27].

Figure 2 describes number of Actinomycetes isolates that grew in HV media agar. Actinomyce- tes isolates grew more slowly on HV media agar with small colony, so it is easily to pick up and purify the isolates before sub cultured onto rich media. The colony forming units (CFU) average numbers of Actinomycetes isolates was $6.57 \times 10^{4}$ $\mathrm{CFU} / \mathrm{g}$ sample. Because of heat pre-treatment process, numbers of non-Actinomycetes bacteria were also reduced. A total of 10 isolates were chosen from the selective isolation petri dishes. The selected colonies showed typical properties of Actinomycetes (four of them sporulated) and produced well developed colonies, although some other did not sporulated when sub cultured onto ISP 2 agar. The isolated Actinomycetes were maintained in $4^{\circ} \mathrm{C}$ for further use.

\section{Antibacterial and antifungal activity}

All the bioassays for antibacterial and antifungal activity were carried out in ISP2 agar plates by dual culture methods. Preliminary screening for antibacterial test revealed that 6 isolates exhibited inhibition activity against several bacterial pathogen, while 4 isolates exhibited antifungal activity against three species of fungal test.

From our assay conditions, inhibition values of antibacterial activity produced by Actinomycetes isolates varying from high level (> $30 \mathrm{~mm}$ ) to low level of inhibition $(<10 \mathrm{~mm})$. Pn-TN2 isolate possessed the highest antibacterial activity following by Pn-TN3 isolate against $B$. subtilis, $E$. coli, and $P$. aeroginosa, but could not inhibit growth of S. marcescens (Figure 3). Several other isolates (Pn-TN5, Pn-Tn6, Pn-Tn7, Pn-Tn8, PnTN9) demonstrated low level of inhibition against several bacterial pathogen (Table 1).

The strongest inhibitory activity of these strain against E. coli suggested that this Actinomycetes isolate was potential for inhibit the growth of Gram negative bacteria rather than Gram positive bacteria even though it is not clear if this activity arise from one, or multiple antimicrobial compounds. This is true even under in vivo conditions, where a cocktail of antimicrobial is expected to assist in nest hygiene [32], but it needs confirmation by further studies.

In this experiment, by comparing the growth of mycelia towards and away we could calculate the inhibition rate produced by Actinomycetes isolates against three species of fungal test (Table 2). From first preliminary screening, only a total of 4 isolates possessed antifungal activity against fu- 


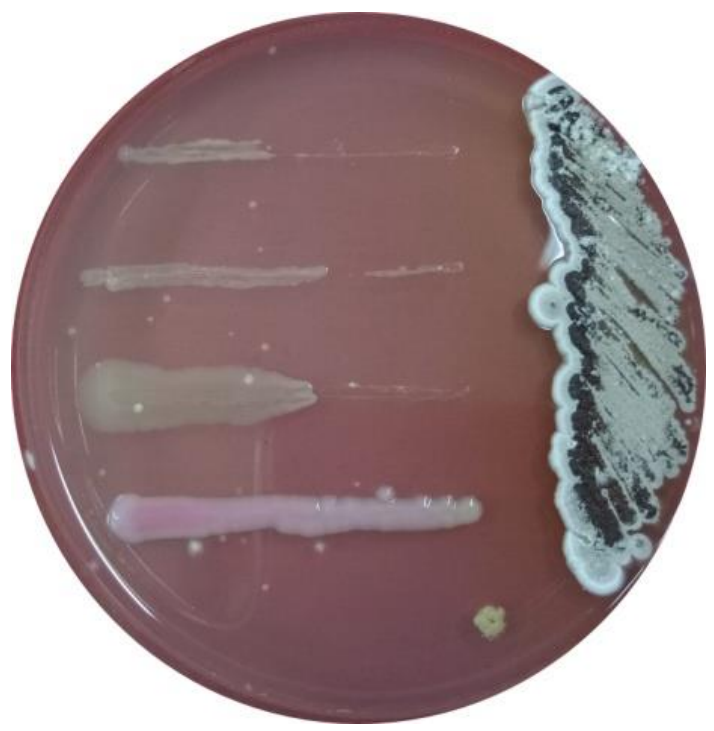

(a)

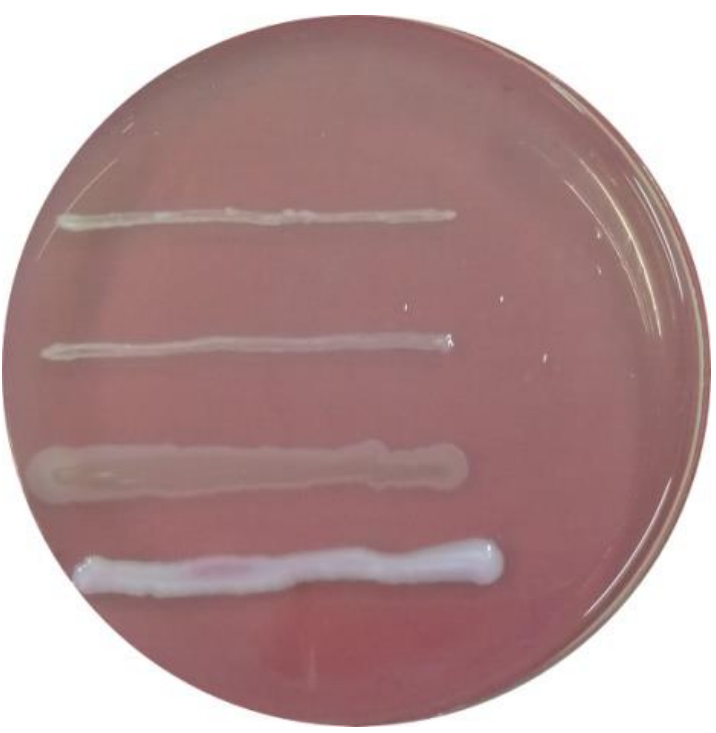

(b)

Figure 3. Antibacterial activity of isolate Pn-TN2 against bacterial pathogen 1. E. coli, 2. S. aureus, 3. B. subtilis, 4. S. marcescens (a) and negative control of bacterial pathogen growth in ISP 2 media (b)

Table 1. Inhibition values and level of inhibition produced by isolated Actinomycetes against bacterial pathogen

\begin{tabular}{rcccccccc}
\hline \multirow{2}{*}{$\begin{array}{c}\text { Code } \\
\text { isolate }\end{array}$} & \begin{tabular}{c} 
B. \\
\cline { 2 - 7 }
\end{tabular} & $\begin{array}{c}\text { Level of } \\
\text { inhibition }\end{array}$ & E. coli & $\begin{array}{c}\text { Level of } \\
\text { inhibition }\end{array}$ & $\begin{array}{c}\text { S. } \\
\text { marcescens }\end{array}$ & $\begin{array}{c}\text { Level of } \\
\text { inhibition }\end{array}$ & $\begin{array}{c}P . \\
\text { aeroginosa }\end{array}$ & $\begin{array}{c}\text { Level of } \\
\text { inhibition }\end{array}$ \\
\hline Pn-TN1 & 0 & - & 0 & - & 0 & - & 0 & - \\
Pn-TN2 & 32 & +++ & 30 & +++ & 0 & - & 41 & +++ \\
Pn-TN3 & 21 & ++ & 3 & + & 0 & - & 45 & +++ \\
Pn-TN4 & 0 & - & 0 & - & 0 & - & 0 & - \\
Pn-TN5 & 10 & + & 0 & - & 0 & - & 3 & + \\
Pn-TN6 & 7 & + & 0 & - & 0 & - & 4 & + \\
Pn-TN7 & 4 & + & 4 & + & 0 & - & 0 & - \\
Pn-TN8 & 9 & + & 7 & + & 0 & - & 6 & + \\
Pn-TN9 & 0 & - & 0 & - & 0 & - & 5 & + \\
Pn-TN10 & 0 & - & 0 & - & 0 & - & 0 & - \\
\hline
\end{tabular}

Table 2. Growth of mycelia and inhibition rate produced by isolated Actinomycetes against fungal pathogen

\begin{tabular}{cccccccccc}
\hline & \multicolumn{4}{c}{ Growth of Mycelia (mm) } & \multicolumn{5}{c}{ Inhibition Rate (\%) } \\
\cline { 2 - 10 } Code Isolate & F. palustris & T. viridae & F. oxysporum & F. palustris & T. viridae & F. oxysporum \\
\cline { 2 - 10 } & a & b & a & b & a & b & & & \\
\hline Pn-TN1 & 16.0 & 25.0 & 26.0 & 30.0 & 13.5 & 29.5 & $36.00 \pm 9.3$ & $13.33 \pm 8.2$ & $54.24 \pm 3.5$ \\
Pn-TN2 & 10.0 & 26.0 & 10.5 & 28.0 & 6.0 & 30.0 & $61.54 \pm 4.2$ & $62.50 \pm 4.4$ & $80.00 \pm 4.7$ \\
Pn-TN5 & 29.0 & 23.5 & 32.5 & 28.5 & 28.5 & 26.5 & 0.00 & 0.00 & 0.00 \\
Pn-TN10 & 40.0 & 26.5 & 31.0 & 31.0 & 32.5 & 35.0 & 0.00 & 0.00 & $7.14 \pm 2.0$ \\
\hline
\end{tabular}

$\mathrm{a}$ : towards value, $\mathrm{b}$ : away value 
ngal test. In the secondary bio-assay, we found that sporulated Actinomycetes isolates (Pn-TN2, Pn-TN1) showed higher antifungal activity than those of non-sporulated isolates (Pn-TN5, PnTN10) against $F$. oxysporum, $T$. viridae, and $F$. palustris. Isolate Pn-TN2 was able to inhibite the mycelial growth of $F$. palustris by $61 \%$, while to T. viridae by $62 \%$, and more than $80 \%$ to $F$. oxysporum (Figure 4 and Table 2). According to all the tested fungi, F. oxysporum was highly sensitive of all the isolates used.

During 7 days of incubation (Figure 5), the lowest diameter growth of 3 species fungal test mycelia was produced by isolate Pn-TN2. Strong inhibition showed by Pn-TN2 isolate compared to control treatment. Isolates Pn-TN1, Pn-TN5, and Pn-TN10 also showed growth inhibition but not significant among other treatment. It was indicated that Pn-TN2 isolates has produced some bioactive compound that able to decreased the strength of fungal cell strongly.

The results indicated that Pn-TN2 isolate that grown on ISP2 agar plate released an extracellular diffusible metabolite that inhibited the mycelial growth of fungal test. The antagonistic potential of Actinomycetes in fungal test involved the production of extracellular hydrolytic enzymes and moreover secondary antifungal compounds [33]. Antifungal compound has classified based on their mechanisms of action, including: covering inhibitors of the synthesis of cell wall components (glucan, chitin, and mannoproteins), sphingolipid synthesis (serine palmitoyltransferase, ceramide synthase, inositol phosphoceramide synthase and fatty acid elongation) and protein synthesis (sordarins) [34].

\section{Molecular identification of potential actinomy- cetes}

Identification based on gene encoding $16 \mathrm{~S}$ rRNA gene was conducted to the potential Actinomycetes isolate that produce antifungal and antibacterial activity, Pn-TN2. 16S rDNA was amplified from the genomic DNA using oligonucleotide primers targeting conserved sequences in the 3' and 5' regions of bacterial $16 \mathrm{~S}$ rDNA. Isolate PnTN2 was identified with almost complete 16S rDNA sequences and matched with high sequence similarity to Streptomyces prasinopilosus (Table 3).

S. prasinopilosus mostly found in soil and wa- ter sources. It has limited aerial mycelium, spore produced late, secreted melanoid pigment, and white with tinge of dark gray colony when grew in malt extract media [35]. The genera of Streptomyces belong to the family Streptomycetaceae, grow as mycelia filaments in soil; their mature colonies may contain two types of mycelia, the substrate mycelium for nutrients absorption and composed of a dense and complex network of hyphae, another part was aerial mycelium which produce spore for reproductive stage [36]. Antibiotic compound that produced by $S$. prasinopilosus was identified as maniwamycins [37], it antibiotic were found to be azoxy substances and showed broad antifungal spectra. Fukumoto [38] found that maniwamycins is able to inhibit violacein synthesis, which is controlled by quorum sensing in Chromobacterium violaceum. Similarly, isolate $S$. prasinopilosus PN-TN2 also interferes with the quorum sensing process in $S$. marcescens so that although the growth of bacteria was not inhibited but they cannot synthesize the red pigment (prodigiosin) which is an important virulence factor and produced by quorum sensing process. From this research, the potency of antimicrobial produced by S. prasinopilosus in defense mechanisms of termites symbion interaction needs further investigation because this species was found dominantly in the nest of termite and may play an important role in the insect microbe symbiosis.

\section{Termite identification and biology}

Identification (morpho-species) and measurement of morphometry (Figure 5, Table 4) towards termites inside nest sample showed they are belonging to the group of Nasutitermes sp. (Nasutitermitinae, Termitidae). Nasutitermitinae groups are included to higher termites equipped by long rostrum as their specific character on the anterior of the head. Fontanelle is existed distally on the tip of the rostrum and they will secret white latex-like substance as their defense mechanism when menaces are approaching. Some of soldier caste in the group of Nasutitermitinae are having their mandible undeveloped as their taxonomical characters [23, 24].

In the genus of Nasutitermes, it can be found wide range of nest building behavior from subterranean galleries to arboreal nest. Nevertheless, this group had strong relation with the utilization of soil as their main parts of nest structure materials. 


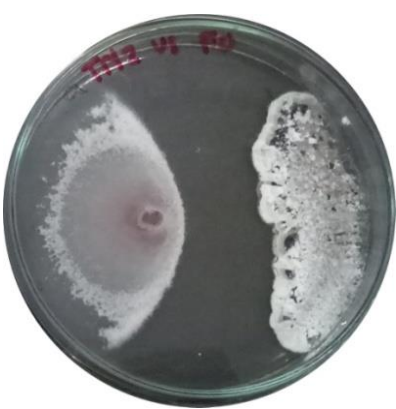

(1a)

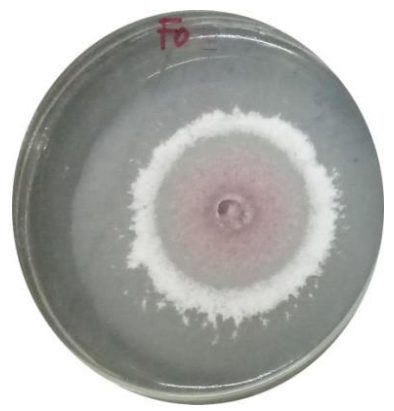

(1b)

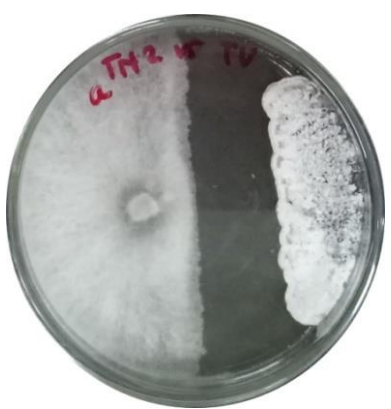

(2a)

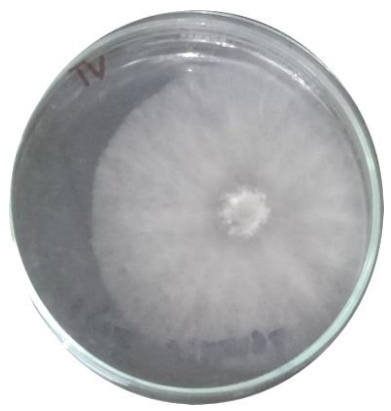

(2b)

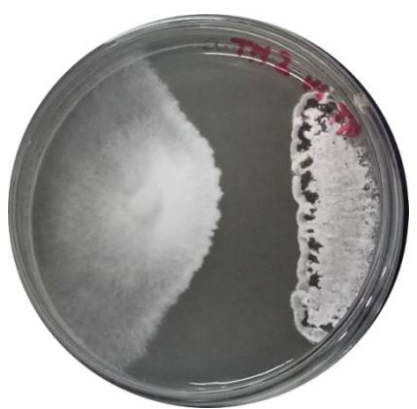

(3a)

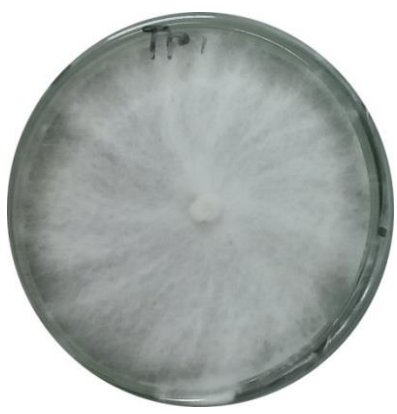

(3b)

Figure 4. Antifungal activity of isolates Pn-TN2 against fungal pathogen (a) and negative control of fungal pathogen growth in ISP 2 media (b). Note: 1. F. oxysporum, 2. T. viridae, 3. F. palustris

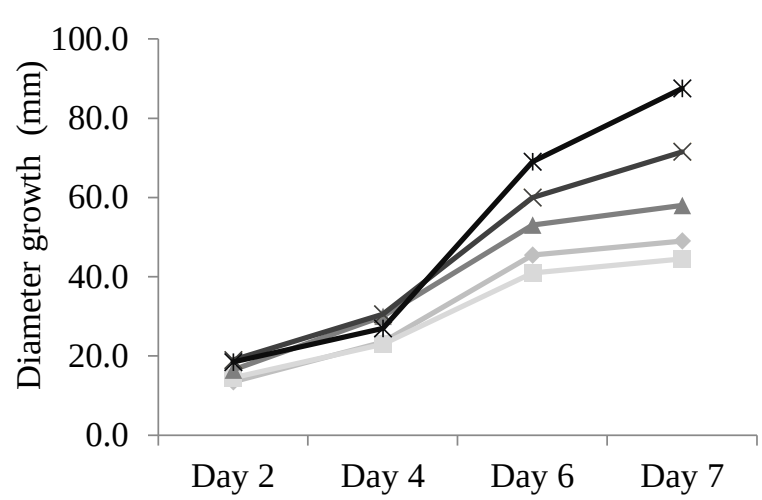

(a)

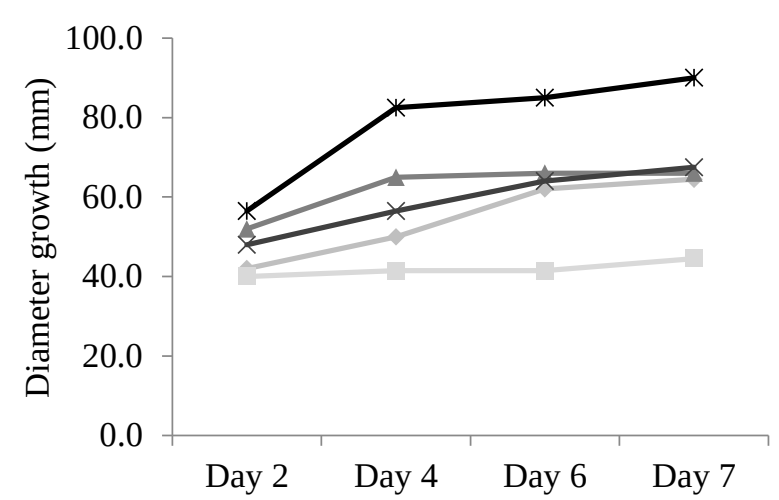

(b)

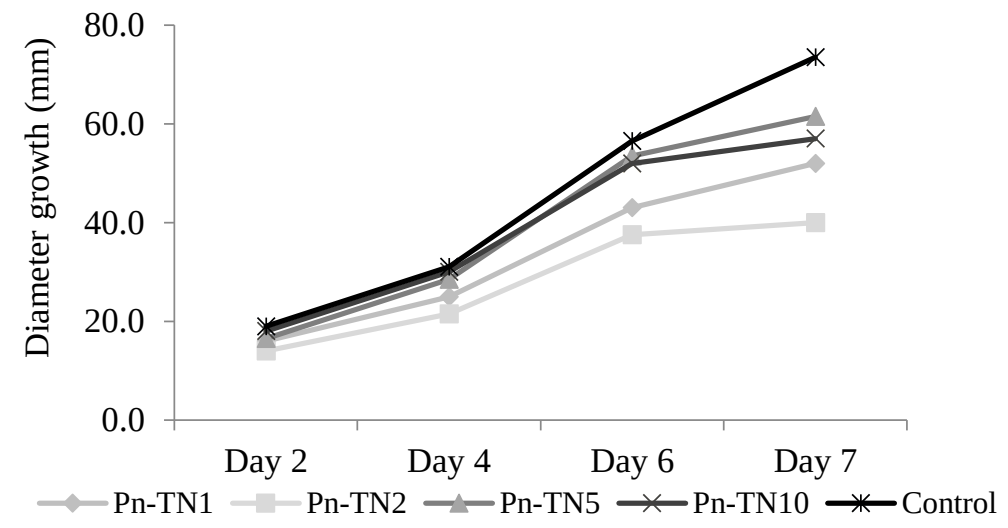

(c)

Figure 5. The diameter growth of mycelia (mm): F. palustris (a), T. viridae (b), F. oxysporum (c) on ISP2 medium that inhibited by Actinomycetes isolates during 7 days of incubation 
Table 3. Identification of potential Actinomycetes isolate by 16S rDNA analysis

\begin{tabular}{cccccc}
\hline Isolate code & BLAST match & Max score & E value & Identification & Accession \\
\hline Pn-TN2 & Streptomyces prasinopilosus strain N2 & 2457 & 0.0 & $99 \%$ & KR703669.1 \\
\hline
\end{tabular}

Table 4. Morphometry measurement of ten soldiers caste of the respective termite

\begin{tabular}{lllllllll}
\hline & $\begin{array}{l}\text { HLr } \\
(\mathrm{mm})\end{array}$ & HL & RL & RI & HW & MHH & PL & PW \\
\hline $\begin{array}{l}\text { Soldiers morphometry } \\
\text { measurement }\end{array}$ & 1.6773 & 1.0457 & 0.6316 & 0.6076 & 1.0743 & 0.8089 & 0.1907 & 0.4984 \\
\hline
\end{tabular}

HLr: Head Length Including rostrum; HL: Head Length without rostrum; RL: Rostrum Length; RI: Rostum index; HW: Head Width; MHH: Max. Height of Head; PL: Pronotum Length; PW: Pronotum Width [24]
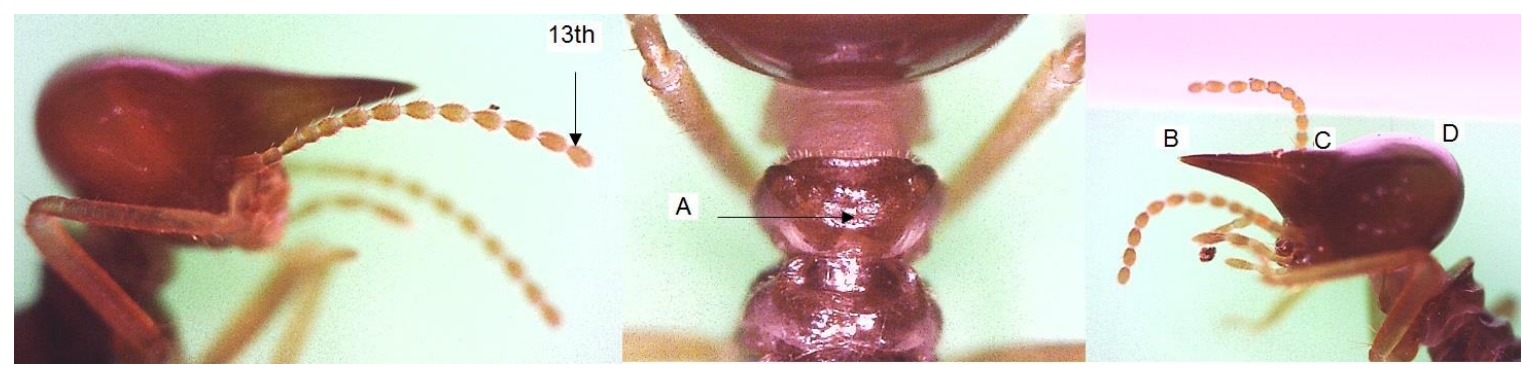

Figure 6. Nasutitermes sp. soldier's head: $13^{\text {th }}$ segment of antennae $\left(13^{\text {th }}\right)$, saddle shaped pronotum (a), rostrum with fontanelle on the tip (b), no constriction behind the base of antennae (c), and posterior of the head is not widened (d)

Additional structures in the nest building are often included plant debris, saliva secretions (found in $N$. triodiae) and excretment (found in N. exitiousus). Most genera of Nasutitermes develop their nest using soil particles brought by worker with their mandible and distribute through all the parts of the nest. How the termite worker distributing the soil is depend on their feeding behavior. Wood feeder usually use mandibles for bringing soil particles and the diameter of soil particles are accustomed to each workers mandibles size (found in $N$. longipennis, $N$. magnus, $N$. triodiae). The other way is through termites' gut which is usually adapted by humus feeder [39]. By building nest away from the soil, Nasutitermes have reduced their interaction with the protective soil environment, making them more susceptible to desiccation, and different predatory pressures [40].

The source of microbial communities in the nest of Nasutitermes was believed from surrounding soil that carrying by worker or soldier termites in their cuticle or in gut system. As we know, each gram of soil contained a million of microorganisms that can be beneficial or not to termites. Pathogen and parasites that contain in soil can be detected and avoided by termites with several disea- se resistance mechanism. A trend in termite evolution of nests was observed progressively reducing contact with soil. The high incidence of entomopathogens in soil were likely involved in the evolution of the more derived nesting habits in $\mathrm{Na}$ sutitermes. Environmental factors such as moisture, temperature, and light may be attributed to characteristic of termite nesting then may lead to influence the composition of microbial communities in termite nest [41].

\section{Conclusion}

The strain S. prasinopilosus Pn-TN2 which isolated from termite nest sample, showed a broad range of antimicrobial activity against bacterial and fungal test. Result showed that this isolate possessed inhibition rate antifungal activity by $80 \%$ against $F$. oxysporum, $61 \%$ against $F$. palustris, and $62 \%$ against $T$. viridae. Advised, this isolate also possessed high antibacterial activity against $B$. subtilis, $P$. aeroginosa, and $E$. coli. Sequence analysis of $16 \mathrm{~S}$ rRNA gene indicated that isolate Pn-TN2 belongs to genus Streptomyces. It shares $99 \%$ similarity with $S$. prasinopilosus. We conclude that termite nest represent source of cultivable Actinomycetes that contribute diverse bio 
active compounds for further biotechnology application in the medical, pharmaceutical, and agricultural fields.

\section{Acknowledgment}

This work was financially supported by Research Center for Biomaterials through "DIPA 2017”. Therefore, we are grateful for this funding and support of this research.

\section{References}

1. Gupte MD, Kulkarni PR (2002) A study of antifungal antibiotic production by Streptomyces chattanoogensis MTCC 3423 using full factorial design. Letters in Applied Microbiology 35 (1): 22 $-26$.

2. Newman DJ, Cragg MG (2007) Natural products as sources of new drugs over the last 25 years. Journal of Natural Products 70 (3): 461 - 477. doi: 10.1021/np068054v.

3. Kumar PS, Duraipandiyan V, Ignacimuthu S (2014) Isolation, screening, and partial purification of antimicrobial antibiotics from soil Streptomyces sp. SCA 7. The Kaohsiung. Journal of Medical Science 30 (9): 435 - 446. doi: 10.1016/j.kjms.2014. 05.006 .

4. Watve MG, Tickoo R, Jog MM, Bhole BD (2001) How many antibiotics are produced by the genus Streptomyces? Archives of Microbiology 176 (5): 386 - 390. doi: 10.1007/s0020301003 45.

5. Subramani R, Aalbersberg W (2012) Marine Actinomycetes: An ongoing source of novel bioactive metabolites. Microbiological Research 167 (10): 571 - 580. doi: 10.1016/j.micres.2012. 06.005 .

6. Dettner K (2011) Potential pharmaceuticals from insects and their cooccurring microorganisms. In: Vilcinskas A (ed) Insect biotechnology. New York, Springer Press. pp 95-119.

7. Berlanga M, Paster BJ, Guerrero R (2009) The taxophysiological paradox: Changes in the intestinal microbiota of the xylophagous cockroach Cryptocercus punctulatus depending on the physiological state of the host. International Microbiology 12: 227 - 236. doi: 10.2436/20.1501.01.102.

8. Robert OE, Frank UO, Agbonsalo OU (2007) Influence of activities of termites on some physical and chemical properties of soils under different land use patterns: A review. International Journal of Soil Science 2 (1): 1 - 14. doi: 10.3923/ijss.2007.1. 14.

9. Verma M, Sharma S, Prasad R (2009) Biological alternatives for termite control: A review. International Biodeterioration and Biodegradation 63 (8): 959 - 972. doi: 10.1016/j.ibiod.2009.05. 009.

10. Khucharoenphaisan K, Sripairoj N, Sinma K (2012) Isolation and identification of Actinomycetes from termite's gut against human pathogen. Asian Journal of Animal and Veterinary Ad- vances 7 (1): 68 - 73. doi: 10.3923/ajava.2012.68.73.

11. Ramin M, Alimon AR, Sijam K, Abdullah N (2008) Filter paper degradation by bacteria isolated from local termite gut. Research Journal of Microbiology 3 (8): 565 - 568. doi: 10.3923/ jm.2008.565.568.

12. Brauman A (2000) Effect of gut transit and mound deposit on soil organic matter transformations in the soil feeding termite: A review. European Journal of Soil Biology 36 (3 - 4): 117 125. doi: 10.1016/S1164-5563(00)01058-X.

13. Sujada N, Sungthong R, Lumyong S (2014) Termite nests as an abundant source of cultivable Actinobacteria for biotechnological purposes. Microbes and Environments 29 (2): 211 - 219. doi: 10.1264/jsme2.ME13183.

14. Holt JA, Lepage M (2000) Termites and soil properties. In: Abe T, Bignell DE, Higashi M (eds) Termites: Evolution, sociality, symbioses, ecology, vol 2. Dordrecht, Kluwer Academic. pp $389-407$

15. Garnier-Sillam E, Toutain F, Renoux J (1988) Comparaison de I'influence de deux termitie`res (humivore et champignonniste) surla stabilite' struc- turale des sols forestiers tropicaux. Pedobiology 32: 89-97.

16. Harry M, Jusseaume N, Gambier B, Garnier-Sillam E (2001) Use of RAPD markers for the study of microbial community similarity from termite mounds and tropical soils. Soil Biology and Biochemistry 33 (4 - 5): 417 - 427. doi: 10.1016/S00380717(00)00181-4.

17. Pasti MB, Pometto AL, Nuti MP, Crowford DL (1990) Ligninsolubilizing ability of Actinomycetes isolated from termite (Termitidae) gut. Applied and Environmental Microbiology 56: $2213-2218$

18. Matsui T, Tanaka J, Namihira T, Shinzato N (2012) Antibiotics production by an Actinomycetes isolated from the termite gut. Journal of Basic Microbiology 52: 731 - 735. doi: 10.1002/jobm.201100500.

19. Schafer A, Konrad R, Kuhnigk T et al. (1996) Hemicellulosedegrading bacteria and yeasts from the termite gut. Journal Applied Bacteriology 80 (5): 471 - 478.

20. Sinma K, Ishida Y, Tamura T et al. (2011) Saccharopolyspora pathumthaniensis sp. nov., a novel Actinomycetes isolated from termite guts (Speculitermes sp.). The Journal of General and Applied Microbiology 57 (2): 93 - 100. doi: 10.2323/jgam.57.93.

21. Kim KH, Ramadhar TR, Beemelmanns C et al. (2014) Natalamycin A, an ansamycin from a termite-associated Streptomyces sp.. Chemical Science 5 (11): 4333 - 4338. doi: 10.1039/C4SC01136H

22. Padilla MA, Rodrigues RAF, Bastos JCS, et al. (2015) Actinobacteria from termite mounds show antiviral activity against bovine viral diarrhea virus, a surrogate model for hepatitis $C$ virus. Evidence-Based Complementary and Alternative Medicines (2015): 1 - 9. doi: 10.1155/2015/745754.

23. Ahmad M (1958) Key to the Indomalayan termites. Lahore, De- 
partment of Zoology University of the Punjab.

24. Syaukani (2010) A guide to the Nasus termites (Nasutitermitinae, Termitidae) of Kerinci Seblat National Park Sumatra. Tokyo, Nagao Natural Environmental Foundation.

25. Kang MJ, Strap JL, Crawford DL (2010) Isolation and characterization of potent antifungal strains of the Streptomyces violaceusniger clade active against Candida albicans. Journal of Industrial Microbiology and Biotechnology 37 (1): 35 - 41. doi: 10.1007/s10295-009-0641-9.

26. Hayakawa M, Yoshida Y, Iimura Y (2004) Selective isolation of bioactive soil Actinomycetes belonging to the Streptomyces violaceusniger phenotypic cluster. Journal of Applied Microbiolog. 96 (5): 973 - 981. doi: 10.1111/j.1365-2672.2004.02230.x

27. Hayakawa M, Nomura H (1987) Humic acid-vitamin agar. A new medium for the selective isolation of soil Actinomycetes. Journal of Fermentation Technology 65 (5): 501 - 509. doi: 10.1016/0385-6380(87)90108-7.

28. Quintana ET, Gill-Rivera DA, Alejo-Vlderique A et al. (2015) Evaluation of the antifungal and antiyeast activities from recently isolated Streptomyces Journal of Pharmaceutical and Biomedical Sciences 5 (11): 867 - 876.

29. Islam MR, Jeong YT, Ryu YJ et al. (2009) Isolation, identification and optimal culture conditions of Streptomyces albidoflavus C247 producing antifungal agents against Rhizoctonia solani. Mycobiology 37 (2): 114 - 120 . doi: 10.4489/MYCO.2009.37.2.114.

30. Kellner RLL (2002) Molecular identification of an endosymbiotic bacterium associated with pederin biosynthesis in Paederus sabaeus (Coleoptera: Staphylinidae). Insect Biochemistry and Molecular Biology 32 (4): 389 - 395. doi: 10.1016/S09651748(01)00115-1.

31. Sunaryanto R, Mahsunah AH (2013) Isolation, purification, and characterization of antimicrobial substances from endophytic Actinomycetes. Makara Journal of Science 17 (3): 87 - 92. doi: 10.7454/mss.v17i3.2947.

32. Kroiss J, Kaltenpoth M, Schneider B et al. (2010) Symbiotic Streptomycetes provide antibiotic combination prophylaxis for wasp offspring. Nature Chemical Biology 6: 261 - 263. doi: 10.1038/nchembio.331.

33. Prapagdee B, Kuekulvong C, Mongkolsuk S (2008) Antifungal potential of extracellular metabolites produced by Streptomyces hygroscopicus against phytopathogenic fungi. International Journal of Biological Sciences 4 (5): 330 - 337. doi:10.7150/ijbs.4.330.

34. Vicente MF, Basilio A, Cabello A, Pelaez F (2002) Microbial natural products as a source of antifungals. Clinical Microbiologi and Infection 9 (1): 15 - 32. doi: 10.1046/j.14690691.2003.00489.x.

35. Ettlinger L, Corbaz R, Hutter R (1958) Zur systematik der Actinomyceten 4. Eine Artenienteilung der Gattung Streptomyces Waksman and Henrici. Archiv für Mikrobiologie 31 (2): 326 358. doi: 10.1007/BF00446537.

36. Hopwood DA (1999) Forty years of genetics with Streptomyces: From in vivo through in vitro to in silico. Microbiology 145: 2183 - 2202. doi: 10.1099/00221287-145-9-2183.

37. Takahashi Y, Nakayama M, Watanabe I et al. (1989) Novel antifungal antibiotics maniwamycins A and B. The Journals of Antibiotics 42 (11): 1535 - 1989. doi: 10.7164/antibiotics.42.1541.

38. Fukumoto A, Murakami C, Anzai Y, Kato F (2016) Maniwamycins: New quorum-sensing inhibitors against Chromobacterium violaceum CV026 were isolated from Streptomyces sp. TOHO-M025. The Journal of Antibiotics 69: 395 - 399. doi: 10.1038/ja.2015.126.

39. Lee KE, Wood TG (1971) Termites and soil. London, Academic Press. pp 27, 41, 147-148.

40. Souza JLP, Moura CAR (2008) Predation of ants and termites by army ants, Nomamyrmex esenbeckii (Formicidae, Ecitoninae) in the Brazilian Amazon. Sociobiology 52 (2): 399 402.

41. Noirot C, Darlington JPEC (2000) Termite nests: architecture, regulation, and defence. In: Abe T, Bignell DE, Higashi M (eds) Termites: Evolution, sociality, symbioses, ecology. Dordrecht, Kluwer Academic Publishers. 